\title{
Temporo-parietal encephalocele: A case report
}

\section{Temporo-parietal ensefalosel: Olgu sunumu}

\author{
Ijpek ULU ${ }^{1}$, Yasemin ÇEKMEZ ${ }^{1}$, Esra TUŞTAŞ HABERAL ${ }^{1}$, Mehmet Serdar GÜLŞEN ${ }^{1}$, Şirin GÜVEN ${ }^{2}$
}

\begin{abstract}
Herniation of the brain tissue with or without meninges through a defect in the calvarium is defined as encephalocele. Most commonly it is seen in the occipital region, the temporal encephalocele constitutes of only $1 \%$ of all cases of encephalocele. A 33year-old woman gravida 5, parity 2, applied to our hospital with the complaint of low back pain at $38+5$ weeks of gestation. On sonographic examination a single viable male fetus appropriate for 38 weeks of gestation was detected. In the calvarium of the fetus a $3 \times 4 \mathrm{~cm}$ mass protruding from the left temporo-parietal region was also detected. Small amount of brain tissue was identified in this mass. Any other fetal extracranial congenital malformations were not detected. Diagnosis of a temporo-parietal encephalocele was made. Encephaloceles are generally prone to be localized at occipital and anterior region of the calvarium. Temporo-parietal location is very rare in the literature. Two dimensional (2D) ultrasound catches nearly $80 \%$ of encephaloceles. Management of encephaloceles depends on the location and size of them. The size of the bulging brain tissue and associated lethal anomalies play role in the decision for the termination of pregnancy. If the brain tissue in the sac is small then the prognosis becomes promising as we expect to be in our case.
\end{abstract}

Keywords: Encephalocele, fetal brain, malformation öz

Beyin dokusunun meninkslerle veya değil, kafatasındaki bir defektten fıtıklaşması ensefalosel olarak tanımlanır. Çoğunlukla oksipital bölgede görülür, temporal ensefalosel tüm ensefalosellerin yalnızca \%1'ini oluşturur. Otuz üç yaşında bir kadın, gravida 5, parite 2, 38 hafta 5 günlük gebeliği mevcutken bel ağrısı ile hastanemize başvurdu. Ultrasonografisinde 38 hafta ile uyumlu tekil, canlı, erkek fetus saptandı. Fetusun kafatasında sol temporoparietal bölgeden protrude olan $3 \times 4 \mathrm{~cm}^{\prime} l i k$ kitle saptandı. Kitle içinde az miktarda beyin dokusu saptandı. Başka bir extrakranyal kongenital malformasyon saptanmadı. Temporo-parietal ensefalosel tanısı koyuldu. Ensefaloseller genellikle kafatasının oksipital veya anterior bölgesinde olmaya meyillidirler. Temporo-parietal yerleşim literatürde oldukça enderdir. Iki boyutlu ultrason ensefalosellerin yaklaşık \%80'ini yakalar. Ensefalosellerin yönetimi yerleşim ve boyutlarına bağlıdır. Gebeliğin sonlandırılması kararında, taşan beyin dokusunun boyutu ve eşlik eden ölümcül anomaliler rol oynar. Kesedeki beyin dokusu küçük ise, o zaman prognoz olgumuzda olmasını beklediğimiz gibi umut verici olur.

Anahtar kelimeler: Ensefalosel, fetal beyin, malformasyon

\section{INTRODUCTION}

Herniation of the brain tissue together with or without meninges through a defect in the calvarium is defined as encephalocele ${ }^{1}$. Its incidence is 0.8-5.6 per 10,000 live births ${ }^{1}$. It's known as a defect of mesoderm. Some enviromental and genetic factors are thought to be the precipitators ${ }^{2}$. Most commonly they are seen in occipital region and frontoethmoidal region is its second common location. It rarely occurs in sphenoidal or parietal region ${ }^{3}$. The temporal encephalocele consists of only $1 \%$ of all cases of encephalocele ${ }^{4}$. Thus the postero-temporo-parietal location of the encephalocele renders our case unusual. Our aim is to draw attention to this rare location of the encephaloceles which can be overlooked.

\section{CASE REPORT}

A 33-year-old pregnant woman gravida 5, parity 2 was admitted to our hospital with the complaint of low back pain at $38+5$ weeks of gestation. She had the history of two spontaneous abortions but no history of rashes, radiation exposure or drug intake.

Received: 26.12 .2015

Accepted: 31.01 .2016

${ }^{1}$ Ümraniye Medical and Research Hospital, Department of Obstetrics and Gynecology

2Ümraniye Medical and Research Hospital, Department of Pediatrics

Yazışma adresi: İpek Ulu, Ümraniye Medical and Research Hospital, Department of Obstetrics and Gynecology, İstanbul

e-mail: dripekulu@gmail.com 
During sonographic examination a single viable male fetus appropriate for 38 weeks of gestation was detected. In the calvarium of the fetus a $3 \times 4 \mathrm{~cm}$ mass was also detected protruding from the left temporoparietal region. Small amount of brain tissue was identified in this mass. Any fetal extracranial congenital malformations were not detected. Diagnosis of a temporo-parietal encephalocele was made. Our patient did not undergo any ultrasonographic exam up to 28 weeks of gestation. The patient confessed that she had been referred to further investigations in her previous prenatal visit but she had refused it, fearing from coming across with the suggestion of termination. During the evaluation process, fetal

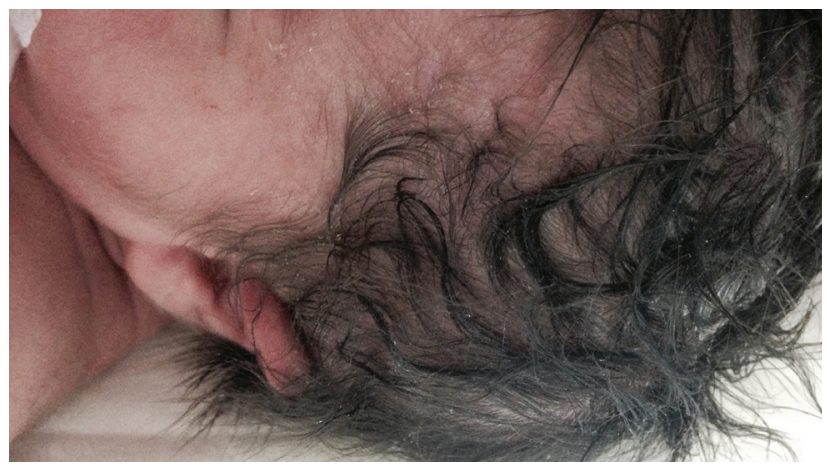

Figure 1. Newborn with the encephalocele.

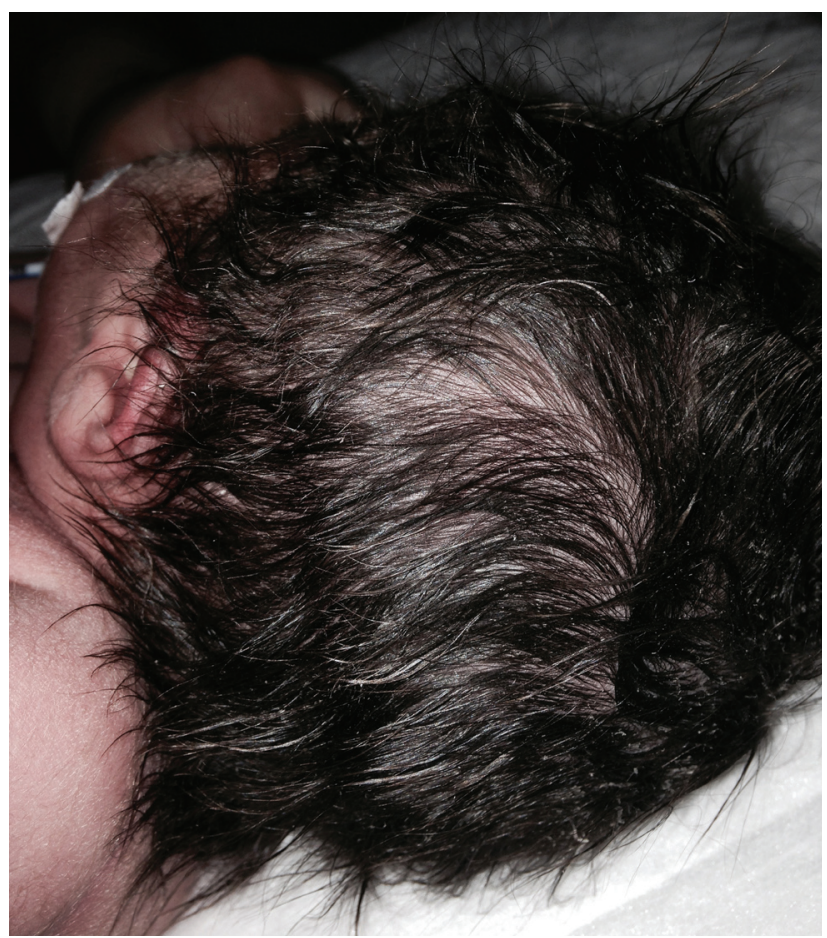

Figure 2. Encephalocele from the lateral view. distress characterized by severe decelerations of fetal heart beats was noticed. An emergency caesarean section was performed. The baby was born with a $3 \times 4$ centimeter $(\mathrm{cm})$ temporo-parietal encephalocele. The lesion was covered with normal skin (Figure 1 and 2). The Apgar scores were 7 and 9 at $1^{\text {st }}$ and $5^{\text {th }}$ minutes respectively.

Postpartum computer tomography (CT) of the neonate showed a $3 \times 4 \mathrm{~cm}$ osseous defect and a $6 \mathrm{~mm}$ parenchymal herniation at the left temporo-parietal region (Figure 3). Parenchymal and extraparenchymal structures of the fetal brain were normal. However myelocortical atrophy and iso-hypodense changes were detected in the herniated parenchyma. The fetal trunk and extremities were normal. Neonatal Magnetic resonance imaging (MRI) also showed the abnormal brain tissue in continuity with normal brain (Figure 3). Detailed neurological and other systemic examinations did not reveal any associated significant anomalies. Excision and repair of the sac together with duraplasty was planned by the neurosurgeons.

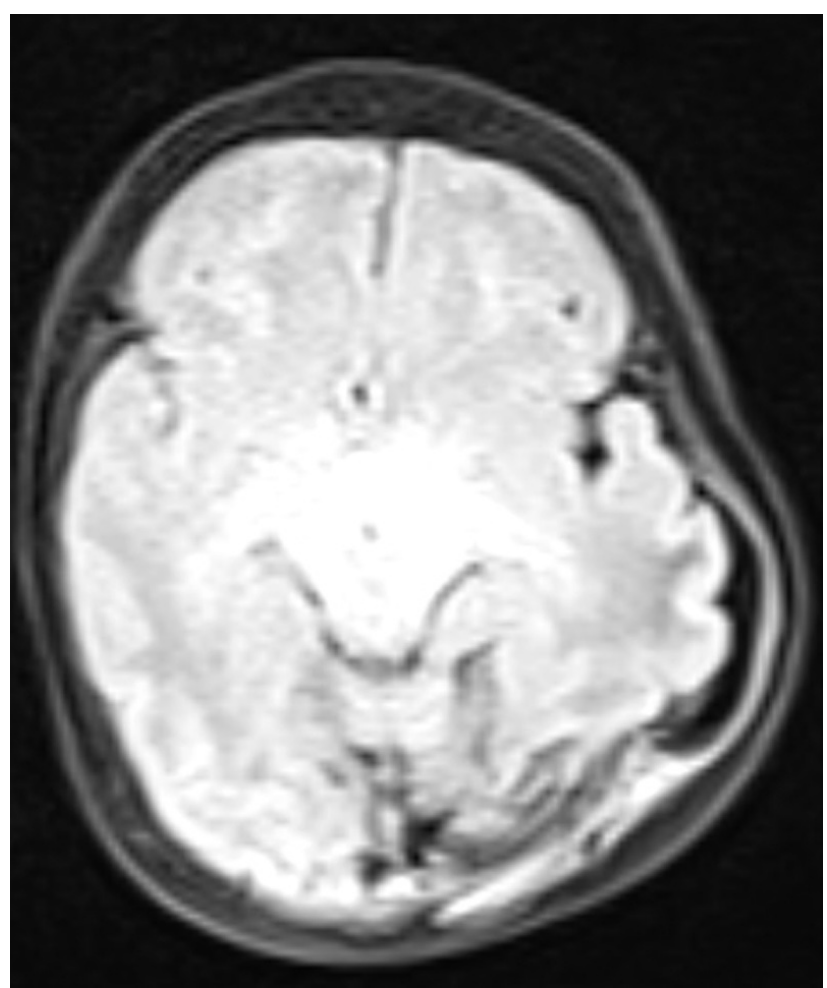

Figure 3. Neonatal MRI demonstrating the encephalocele with abnormal brain tissue in continuity with normal brain. 


\section{DISCUSSION}

Encephaloceles generally present themselves at occipital and anterior region of the calvarium ${ }^{5}$. Temporoparietal location is very rare in the literature. Nagulich et al. ${ }^{6}$ reported eight cases of temporal encephalocele. Only four out of 419 cases of encephalocele reported by Arseni and Horvath involved temporal region ${ }^{7}$. In our case the encephalocele was located in postero-temporo-parietal region which constitutes $1 \%$ of all encephaloceles.

Defective closure of the anterolateral fontanelle (pterion), where the temporal, parietal, frontal bones and the greater wing of the sphenoid bone join may result in this type of encephalocele. The underlying cause is not a genetic mutation or a chromosomal abnormality in most of the cases ${ }^{1}$. Environmental and genetic factors are thought to be involved ${ }^{8}$. In our case there is not any other concomitant congenital malformation. Unlike our case, female gender predisposes more frequently to develop this anomaly according to the literature ${ }^{1}$.

Prenatal diagnosis of encephalocele can be possible with measuring maternal serum alpha-fetoprotein levels and performing ultrasonographic examinations (US) ${ }^{9}$. Two dimensional (2D) ultrasound catches nearly $80 \%$ of encephaloceles ${ }^{10}$. We also diagnosed the encephalocele in our case using 2D ultrasound. It is usually shown as a solid or a cystic brain lesion bulging through a defect in the calvarium ${ }^{11}$. For the diagnosis of small encephaloceles, MRI is more use$\mathrm{ful}^{12}$. We did not have a chance of performing MRI because of the presence of acute fetal distress.

Management of encephaloceles depends on the location and size of them. Prognosis of occipital encephaloceles is worse due to the strong association with other malformations ${ }^{13}$. Parietal encephaloceles also have bad prognosis when they are associated with brain malformations ${ }^{14}$. In our case the temporoparietal location is thought to give the patient the chance of close to normal neurological development. Besides, small size of the encephalocele in our case contributed to the good prognosis of the disease. The size of the bulging brain tissue and associated lethal anomalies play role in the decision of termination of the pregnancy. If the brain tissue in the sac is small then the prognosis becomes promising as we expect to be in our case. Anyway his parents did not hesitate to continue with the pregnancy.

Neurological development of the neonate born with the temporal encephalocele is generally close to normal but psychomotor retardation has been reported in the literature ${ }^{6}$. Complete excision of the lesion is suggested in these encephaloceles. This localization of the encephalocele that differentiates our case from the others should be kept in mind when a calvarial asymmetry is detected.

\section{Conflict of Interests}

The authors have not declare any conflict of interest.

\section{REFERENCES}

1. Dadmehr M, Nejat F, Khashab ME, et al. Risk factors associated with occipital encephalocele: a case-control study. J Neurosurg Pediatrics 2009;3:534-37. http://dx.doi.org/10.3171/2009.2.PEDS08436

2. Sadewa $A H$, Sutomo $R$, Istiadjid $M$, et al. C677T mutation in the MTHFR gene was not found in patients with frontoethmoidal encephalocele in East Java, Indonesia. Pediatr Int 2004;46:409-14.

http://dx.doi.org/10.1111/j.1442-200x.2004.01927.x

3. Raja RA, Qureshi AA, Memon AR, et al. Pattern of encephaloceles: a case series. J Ayub Med Coll Abbottabad 2008;20:125-28.

4. French BN. Midline fusion defects and defects of formation. In: Neurological Surgery. Youmans JR (ed). Saunders, Toronto, 1982: 1236-1380.

5. Mahapatra AK. Anterior encephalocele: AlIMS experience a series of 133 patients. J Pediatr Neurosci 2011;6(Suppl 1):27-30. http://dx.doi.org/10.4103/1817-1745.85706

6. Nagulich I, Borne G, Georgevich Z. Temporal meningocele. J Neurosurg 1967;27:433-40.

http://dx.doi.org/10.3171/jns.1967.27.5.0433

7. Arseni C, Horvath L. Meningoencephalocele of the pterion. Acta Neurochir (Wien) 1971;25:231-40. http://dx.doi.org/10.1007/BF01809105

8. Jalali A, Aldinger KA, Chary A, et al. Linkage to chromosome 2q36.1 in autosomal dominant Dandy-Walker malformation with occipital cephalocele and evidence for genetic heterogeneity. Hum Genet 2008;123:237-45.

http://dx.doi.org/10.1007/s00439-008-0467-y

9. Mahapatra AK, Suri A. Anterior encephaloceles: a study of 92 cases. Pediatr Neurosurg 2002;36:113-8.

http://dx.doi.org/10.1159/000048365 
10. Borowski D, Wegrzyn P, Bartkowiak R, et al. First trimester diagnosis of encephalocele-report of two cases and review of the literature. Ginekol Pol 2011;82:700-4.

11. Graham D, Johnson TR Jr, Winn K, Sanders RC. The role of sonography in the prenatal diagnosis and management of encephalocele. J Ultrasound Med 1982;1:111-5.

12. Morioka T, Hashiquchi K, Samura K. et al. Detailed anatomy of intracranial venous anomalies associated with atretic parietal cephaloceles revealed by high-resolution 3D-CISS and high-field T2-weighted reversed MR images. Childs Nerv Syst
2009;25:309-15

http://dx.doi.org/10.1007/s00381-008-0721-6

13. Nath HD, Mahapatra AK, Borkar SA. A giant occipital encephalocele with spontaneous hemorrhage into the sac: A rare case report. Asian J Neurosurg 2014;9:158-60. http://dx.doi.org/10.4103/1793-5482.142736

14. Yokota A, Kajiwara H, Kohchi M, et al. Parietal cephalocele: clinical importance of its atretic form and associated malformations. J Neurosurg 1988;69:545-51.

http://dx.doi.org/10.3171/jns.1988.69.4.0545 